\title{
Design Principle of Conjugated Polyelectrolytes to Make Them Water-Soluble and Highly Emissive
}

\author{
Kangwon Lee, Hyong-Jun Kim, and Jinsang Kim*
}

The correlation between the molecular design of a conjugated polyelectrolyte (CPE) and its aggregated structure and the emissive properties in water is systematically investigated by means of UV-vis spectrometry, fluorescence spectroscopy, and scanning/transmission electron microscopy. Five different and rationally designed CPEs having carboxylic acid side chains are synthesized. All five conjugated polyelectrolytes are seemingly completely soluble in water in visual observation. However, their quantum yields are dramatically different, changing from 0.45 to $51.4 \%$. Morphological analysis by electron microscopy combined with fluorescence spectrophotometry reveals that the CPEs form self-assembled aggregates at the nanoscale depending on the nature of their side chains. The feature of the self-assembled aggregates directly determines the emissive property of the CPEs. The nature and the length of the spacer between the carboxylic acid group and the CPE backbone have a strong influence on the quantum yield of the CPEs. Our study demonstrates that bulky and hydrophilic side chains and spacers are required to achieve complete water-solubility and high quantum yield of CPEs in water, providing an important molecular design principle to develop functional CPEs.

\section{Introduction}

A conjugated polyelectrolyte $(\mathrm{CPE})^{[1,2]}$ a conjugated polymer containing a charged (anionic or cationic) group, has received considerable attention for its bio-applications such as solution-based DNA sensor, ${ }^{[3-11]}$ DNA microarray, ${ }^{[12-14]}$ protein sensor, ${ }^{[15-24]}$ bioimaging ${ }^{[25-28]}$ as well as optoelectronic applications such as organic semiconductors, ${ }^{[29-31]}$ light-emitting devices, ${ }^{[32,33]}$ and actuators. ${ }^{[34]}$ The ionic side group plays an important role to provide CPEs with water-solubility that is central to many

Dr. K. Lee, ${ }^{[+]}$Dr. H.-J. Kim, ${ }^{[+]}$Prof. J. Kim Department of Materials Science and Engineering University of Michigan

Ann Arbor, MI 48109, USA

E-mail: jinsang@umich.edu

Prof. J. Kim

Department of Chemical Engineering

Macromolecular Science and Engineering

Biomedical Engineering

University of Michigan

Ann Arbor, MI 48109, USA

[+] Present address: School of Engineering and Applied Science,

Harvard University, MA, USA

$[++]$ Present address: College of Engineering, Kongju National University

DOI: 10.1002/adfm.201102027 biological applications. In addition, maintaining the emissive property of a CPE in aqueous solution is another requirement for many biosensor applications because the merit of using conjugated polymers as a sensor is their amplified fluorescence signaling property upon environmental changes. ${ }^{[35-45]}$

However, in this regard, CPE inherently has a critical solubility limitation in aqueous environment because the $\pi$-conjugated polymer backbone is chemically hydrophobic and structurally rigid. The rigid-rod and hydrophobic nature of CPEs induces polymer aggregation via intermolecular hydrophobic interaction among the polymer backbones in aqueous environment. ${ }^{[37,38,46]}$ Therefore, the solubility of CPE in water is significantly low, consequently inducing significant decrease in the fluorescence quantum yield due to the aggregation-induced self-quenching. ${ }^{[47-51]}$

Moreover, once CPEs are completely dried, it is tremendously difficult to re-dissolve them in water due to the rigid hydrophobic nature of the backbone and resulting strong and cohesive aggregation. Besides the solubility issue, there is another requirement for CPE to be useful for biological applications. To achieve efficient and convenient bio-conjugation between the CPE and a biological molecule, CPEs should have an efficient and convenient functional group such as a carboxylic acid group or an amine group. ${ }^{[52,53]}$ Due to these demanding requirements, it remains a difficult task to develop highly emissive and completely water-soluble functional CPEs.

Several research groups have developed CPE-based functional systems by utilizing the emissive property of CPEs. Leclerc et al. developed DNA sensors using cationically charged polythiophene derivatives. Charge-charge interaction between the cationic CPE and a single strand DNA and subsequent detection of the complementary DNA produces a conformation change of the CPE and consequent color change as a sensory signal. ${ }^{[7,15,54-57]}$ Bazan and co-workers have reported signal amplifying biosensors based on cationically charged CPEs and fluorescence resonance energy transfer (FRET). ${ }^{[4]}$ Schanze et al. investigated CPE systems and reported amplified fluorescence quenching of sulfonated CPEs due to $\pi-\pi$ aggregation of the rigid linear CPEs in aqueous media. ${ }^{[37,38,40]}$ Bunz and coworkers have investigated $\mathrm{pH}$-dependent optical properties of CPEs by modulating carboxylic acid side-chain. ${ }^{[58]}$ Furthermore, cationic gold nanoparticles conjugated with carboxylated CPEs 
polyelectrolytes have successfully been developed for bacteria identification vehicles. ${ }^{[59]}$ Recently, completely water-soluble CPEs have been also reported. ${ }^{[33,60]}$ Understanding the correlation among the quenching dynamics, the chemical structure of receptor-functionalized CPEs, and the fluorescence efficiency is critically important to develop biosensory materials based on water-soluble CPEs. However, to our knowledge there has not been any article that comprehensively and systematically provides design principles to develop highly emissive and completely water-soluble CPEs.

We have rationally designed and prepared a series of PPEbased CPEs and systematically investigated the effects of the side chain structure on the solubility and the fluorescence quantum yield of the CPEs in aqueous environment. Here, we report our comprehensive quantum yield study, scanning transmission electron microscopy and conventional/cryogenic transmission electron microscopy (TEM) study to reveal the correlation among the chemical and structural characteristics of the side chain of the CPEs, their molecular assembly, and their emissive property. We chose carboxylic acid moiety for this study as a pendant ionic group considering that it is the most convenient functional group for bioconjugation with the ubiquitous amine group present in biological molecules. As the molecular design parameter, we controlled the bulkiness of the side chain, the length of the linker molecule between the conjugated backbone and the carboxylic acid group, and the hydrophobic and hydrophilic property of the linker as illustrated in Figure 1.

\section{Results and Discussion}

\subsection{Synthesis of the Monomers and Polymers (P1-P5)}

Synthesis of Bis(2-ethylhexyl) 2,5-diiodoterephthalate (M1): 2,5-diiodoterephthalic acid (1, $0.3 \mathrm{~g}, 0.72 \mathrm{mmol})$, 2-ethyl-1hexanol $(0.28 \mathrm{~g}, 2.16 \mathrm{mmol})$, toluene $(20 \mathrm{~mL})$, and $0.1 \mathrm{~mL}$ of concentrated $\mathrm{H}_{2} \mathrm{SO}_{4}$ were heated for $24 \mathrm{~h}$ to reflux, with separation of the water using a Dean-Stark trap. Reaction mixture was cooled down and the organic layer was washed with water and dried with $\mathrm{MgSO}_{4}$. Further purification was done by column chromatography (ethyl acetate: hexane $=1: 15 \mathrm{v} / \mathrm{v}$ ) to get viscous yellow oil $(0.14 \mathrm{~g}, 30 \%) .{ }^{1} \mathrm{H}-\mathrm{NMR}\left(500 \mathrm{MHz}, \mathrm{CDCl}_{3}\right): \delta /$ ppm 8.26 (s, 2H, aromatic), 4.27 (d, $\left.4 \mathrm{H},-\mathrm{OCH}_{2^{-}}\right), 1.79(\mathrm{~m}, 2 \mathrm{H}$, - $\mathrm{CH}-), 1.55-1.30\left(\mathrm{~m}, 16 \mathrm{H},-\mathrm{CH}_{2^{-}}\right), 0.95\left(\mathrm{~m}, 12 \mathrm{H}, \mathrm{CH}_{3}\right) .{ }^{13} \mathrm{C}-\mathrm{NMR}$ $\left(125 \mathrm{MHz}_{\mathrm{CDCl}}\right.$ ): $\delta / \mathrm{ppm} 165.5,139.9,138.1,92.7,68.6,38.9$, 30.6, 29.0, 24.0, 23.0, 14.1, 11.1. HRMS (Voltage EI+): calculated $\mathrm{m} / \mathrm{z}$ of $[\mathrm{M}+]$ 642.0691; measured m/z 642.0679.

Diethyl 4,4'-(2,5-diiodo-1,4-phenylene)bis(oxy)dibutanoate (M2): To a solution of 2,5-diiodo-1,4-hydroquinone (2, $1.0 \mathrm{~g}, 2.76 \mathrm{mmol})$ were added a potassium carbonate $(1.615 \mathrm{~g}$, $8.28 \mathrm{mmol}$ ), ethyl 4-bromobutyrate (1.615 g, $8.28 \mathrm{mmol})$ and DMF $(15 \mathrm{~mL})$ and reaction mixture was stirred at $80{ }^{\circ} \mathrm{C}$ for $48 \mathrm{~h}$. After the reaction, reaction mixture was cooled down and filtered. DMF was removed with rotary evaporator at reduced pressure. Crude mixture was re-dissolved in chloroform and extracted twice with deionized water. After drying over $\mathrm{MgSO}_{4}$ and filtering, chloroform was removed in vacuo. Further purification was done by column chromatography (ethyl acetate: hexane $=1: 1 \mathrm{v} / \mathrm{v}$ ) and the following recrystallization in methanol at $-18{ }^{\circ} \mathrm{C}$ to give white waxy powder (yield: $0.65 \mathrm{~g}, 41 \%$ ). ${ }^{1} \mathrm{H}-\mathrm{NMR}\left(500 \mathrm{MHz}, \mathrm{CDCl}_{3}\right): \delta / \mathrm{ppm} 7.10$ (s, 2H, aromatic), $4.20\left(\mathrm{~m}, 4 \mathrm{H},-\mathrm{OCH}_{2} \mathrm{CH}_{3}\right), 4.01$ (t, 4H, $\left.-\mathrm{OCH}_{2}-\right), 2.60$ (t, $4 \mathrm{H}$, $\left.-\mathrm{CH}_{2} \mathrm{COO}-\right), 2.15$ (m, 4H, - $\left.\mathrm{CH}_{2}-\right), 1.27$ (t, 6H, - $\left.\mathrm{CH}_{3}\right) \cdot{ }^{13} \mathrm{C}-\mathrm{NMR}$ $\left(125 \mathrm{MHz} \mathrm{CDCl}_{3}\right): \delta / \mathrm{ppm} 173.1,152.7,122.5,86.1,69.9,60.3$, 30.6, 24.4, 14.1. Elemental analysis calcd; C 36.63, H: 4.10, obsd; C: 36.71, H: 4.15.

Diethyl 7,7'-(2,5-diiodo-1,4-phenylene)bis(oxy)diheptanoate (M3): Synthetic procedure for this compound is the same as that for M2 except for using ethyl 7-bromoheptanoate (2 g, $8.43 \mathrm{mmol}$ ) as a reactant and different column eluent (ethyl acetate: hexane $=1: 4 \mathrm{v} / \mathrm{v}$ ) for column purification (yield: $0.89 \mathrm{~g}$, 47\%). ${ }^{1} \mathrm{H}-\mathrm{NMR}\left(500 \mathrm{MHz}, \mathrm{CDCl}_{3}\right): \delta / \mathrm{ppm} 7.18$ (s, 2H, aromatic $\mathrm{C}-\mathrm{H}), 4.15$ (m, 4H, COO- $\left.\mathrm{CH}_{2}-\mathrm{CH}_{3}\right), 3.94$ (t, 4H, O-CH $\left.2^{-}\right), 2.33$
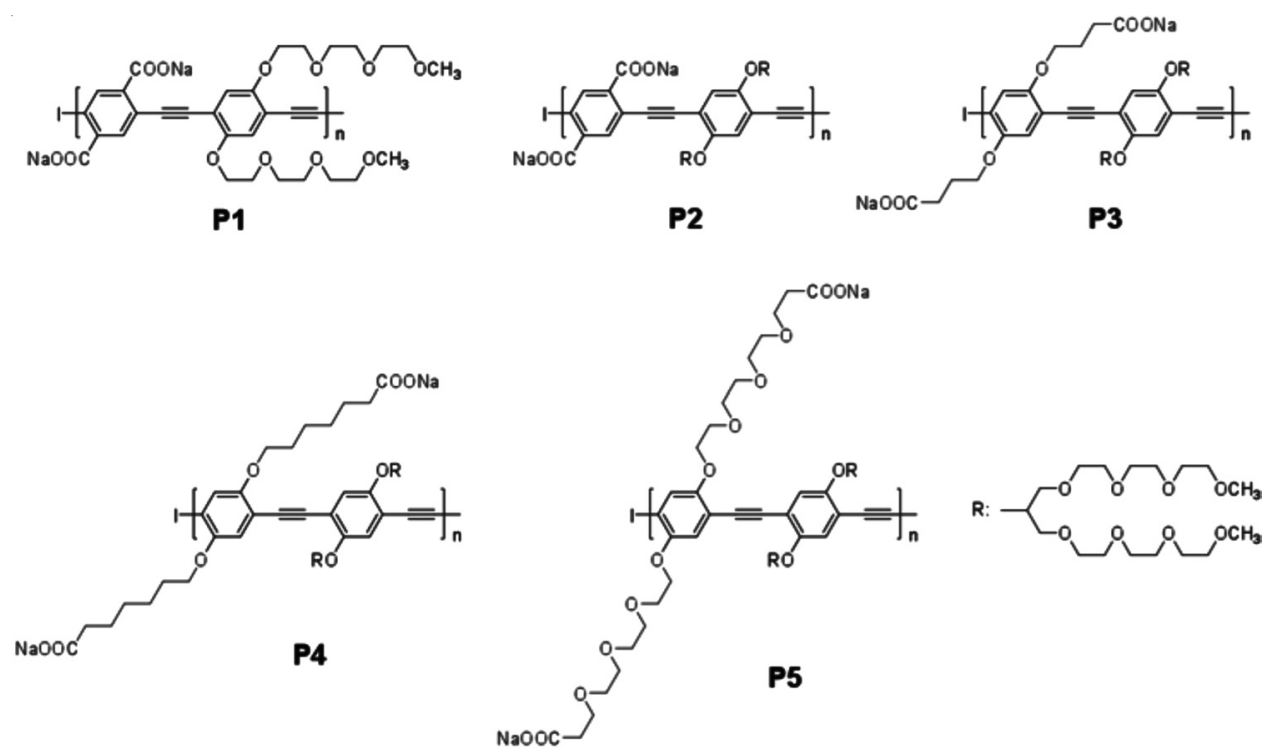

Figure 1. The chemical structure of the CPEs (P1-P5). 
(t, 4H, $\left.\mathrm{CH}_{2}-\mathrm{CH}_{2}-\mathrm{CO}-\right), 1.82\left(\mathrm{~m}, 4 \mathrm{H},-\mathrm{CH}_{2}-\right), 1.69$ (m, 4H, $-\mathrm{CH}_{2}-$ ), $1.54\left(\mathrm{~m}, 4 \mathrm{H},-\mathrm{CH}_{2}-\right), 1.42\left(\mathrm{~m}, 4 \mathrm{H},-\mathrm{CH}_{2}^{-}\right), 1.27$ (t, 6H, $\left.-\mathrm{CH}_{3}\right)$. ${ }^{13} \mathrm{C}-\mathrm{NMR}\left(125 \mathrm{MHz}, \mathrm{CDCl}_{3}\right): \delta / \mathrm{ppm} 173.1,152.7,122.5,86.1$, 70.1, 60.3, 33.5, 31.3, 29.1, 25.7, 25.5, 14.1. Elemental analysis calcd; C 42.75, H: 5.38, obsd; C: 42.85, H: 5.40.

Tert-butyl 3-(2-(2-(2-hydroxyethoxy)ethoxy)ethoxy)propanoate (3): This compound was prepared by procedure in a previous literature through a slight modification. ${ }^{52]}$ In $1000 \mathrm{~mL}$ of 2-necked round-bottomed flask, triethylene glycol $(128 \mathrm{~mL}$, $0.40 \mathrm{~mol})$ is dissolved in $500 \mathrm{~mL}$ of THF. $0.34 \mathrm{~g}(14.8 \mathrm{mmol})$ of sodium lump was sliced and added to the solution under argon purging. The solution was vigorously stirred to dissolve sodium completely. After no more gas or bubble, tert-butyl acrylate $(48 \mathrm{~mL}, 0.33 \mathrm{~mol})$ was added to the solution. The reaction solution was stirred under argon atmosphere at room temperature for $20 \mathrm{~h}$. The solution was neutralized with $1 \mathrm{M} \mathrm{HCl}$ and THF was evaporated at reduced pressure. Crude compound was suspended to saturated brine and extracted with ethyl acetate. Organic layer was washed with saturated $\mathrm{NaCl}$ solution and water again and dried over anhydrous $\mathrm{MgSO}_{4}$ (yield: $58.5 \mathrm{~g}$, 53\%). ${ }^{1} \mathrm{H}-\mathrm{NMR}\left(500 \mathrm{MHz}, \mathrm{CDCl}_{3}\right): \delta / \mathrm{ppm} 3.75-3.21(\mathrm{~m}, 14 \mathrm{H}$, $-\mathrm{OCH}_{2}^{-}$), 2.69 (broad s, $\left.1 \mathrm{H}, \mathrm{OH}\right), 2.51$ (t, 2H, - $\left.\mathrm{CH}_{2} \mathrm{COO}-\right), 1.45$ (s, 9H, -C(CH$\left.)_{3}\right) .{ }^{13} \mathrm{C}-\mathrm{NMR}(125 \mathrm{MHz}, \mathrm{CDCl} 3)$ : $\delta / \mathrm{ppm} 28.2$, 36.3, 61.7, 66.9, 70.4, 70.5, 70.6, 70.7, 80.6, 171.0.

Tert-butyl3-(2-(2-(2-(toluenesulfonyloxy)ethoxy)ethoxy)ethoxy)propanoate (4): Compound 3 (58.5 g, $0.21 \mathrm{~mol}$ ) and triethylamine $(171 \mathrm{~mL})$ was dissolved in anhydrous dichloromethane $(290 \mathrm{~mL})$ and the solution was cooled down to $4{ }^{\circ} \mathrm{C}$ using iced bath. $p$-toluenesulfonyl chloride (46.82 g, $0.245 \mathrm{~mol}$ ) in $100 \mathrm{~mL}$ of dichloromethane was added dropwise. The temperature of reaction solution was slowly increased to room temperature and the solution was stirred overnight. After the reaction, the solution was poured into $1300 \mathrm{~mL}$ of $1 \mathrm{M} \mathrm{HCl}$ and the aqueous phase is removed. Organic phase was washed with saturated $\mathrm{NaCl}$ solution and dried over $\mathrm{MgSO}_{4}$. The compound was purified by column chromatography (ethyl acetate: hexane $=1$ : $1 \mathrm{v} / \mathrm{v}$ ) (yield: $69.9 \mathrm{~g}, 77 \%$ ). ${ }^{1} \mathrm{H}-\mathrm{NMR}\left(500 \mathrm{MHz}, \mathrm{CDCl}_{3}\right.$ ): $\delta / \mathrm{ppm}$ $7.60(\mathrm{~d}, \mathrm{~J}=5 \mathrm{~Hz}, 2 \mathrm{H}$, aromatic $\mathrm{H}), 7.18(\mathrm{~d}, \mathrm{~J}=5 \mathrm{~Hz}, 2 \mathrm{H}$, aromatic $\mathrm{H}$ ), 3.97 (t, $2 \mathrm{H}, \mathrm{S}-\mathrm{O}-\mathrm{CH}_{2}$ ), 3.58-3.31 (m, $12 \mathrm{H},-\mathrm{O}-\mathrm{CH}_{2-}$ ), 2.29 (t, $\left.2 \mathrm{H},-\mathrm{CH}_{2}-\mathrm{COO}\right), 2.25\left(\mathrm{~s}, 3 \mathrm{H}, \mathrm{Ar}-\mathrm{CH}_{3}\right), 1.25$ (s, 9H, $\left.\mathrm{C}\left(\mathrm{CH}_{3}\right)_{3}\right) .{ }^{13} \mathrm{C}-\mathrm{NMR}(125 \mathrm{MHz}, \mathrm{CDCl} 3): \delta / \mathrm{ppm} 21.8,28.2,36.4$, 67.0, 68.8, 69.4, 70.5, 70.6, 70.7, 70.8, 80.6, 128.1, 130.0, 133.1, 144.9, 171.0. HRMS $\left(\mathrm{C}_{20} \mathrm{H}_{32} \mathrm{O}_{8} \mathrm{~S}+\mathrm{Na}\right)$ : calculated $\mathrm{m} / \mathrm{z}$ of $[\mathrm{M}+\mathrm{Na}]$ 455.1705; measured $\mathrm{m} / \mathrm{z} 455.1714$.

1,4-diiodo-2,5-bis(11-(tert-butoxycarbonyl)-3,6,9-trioxaundecyloxy)benzene (5): Compound 4 (11.28 g, $26.08 \mathrm{mmol})$, compound 2 (3.93 g, $10.87 \mathrm{mmol}$ ), potassium iodide $(0.018 \mathrm{~g}$, $0.11 \mathrm{mmol})$, potassium carbonate $(9 \mathrm{~g}, 65.22 \mathrm{mmol})$ and $30 \mathrm{~mL}$ of 2-butanone were added to a $250 \mathrm{~mL}$ of two neck roundbottomed flask with condenser. Reaction solution was refluxed for $38 \mathrm{~h}$ and 2-butanone was evaporated at reduced pressure. The crude mixture was suspended to methylene chloride and washed with $1 \mathrm{M} \mathrm{HCl}$. The organic layer was again washed with saturated $\mathrm{NaCl}$ and dried over $\mathrm{MgSO}_{4}$. Further purification was achieved by column chromatography on sllica gel (ethyl acetate: hexanes $=7: 3 \mathrm{v} / \mathrm{v}$ ). Compound was again chromatographed on silica gel (ethyl acetate: hexanes = 1:1 v/v) (yield: $4.26 \mathrm{~g}, 44 \%$ ). ${ }^{1} \mathrm{H}-\mathrm{NMR}$ (500 MHz, CDCl 3 ): $\delta / \mathrm{ppm} 7.22$ (s, 2H, aromatic), 4.15 $\left(\mathrm{t}, 4 \mathrm{H},-\mathrm{OCH}_{2^{-}}\right), 3.87\left(\mathrm{t}, 4 \mathrm{H},-\mathrm{OCH}_{2^{-}}\right)$, 3.8-3.6 (m, 20H, $-\mathrm{OCH}_{2^{-}}$),
2.51 (t, 4H, - $\left.\mathrm{CH}_{2} \mathrm{COO}-\right), 1.42\left(\mathrm{~s}, 18 \mathrm{H},-\mathrm{C}\left(\mathrm{CH}_{3}\right)_{3}\right),{ }^{13} \mathrm{C}-\mathrm{NMR}$

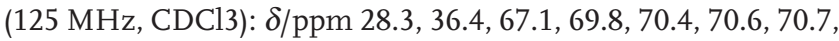
70.8, 80.7, 86.6, 123.6, 153.3, 171.1. HRMS $\left(\mathrm{C}_{32} \mathrm{H}_{52} \mathrm{I}_{2} \mathrm{O}_{12}+\mathrm{Na}\right)$ : calculated $\mathrm{m} / \mathrm{z}$ of 905.1435 ; measured $\mathrm{m} / \mathrm{z}$ 905.1442.

1,4-diiodo-2,5-bis(11-carboxy-3,6,9-trioxaundecyloxy)benzene (M4): To a $4.00 \mathrm{~g}(4.53 \mathrm{mmol})$ of compound 5 was added $85 \mathrm{~mL}$ of trifluoroacetic acid $\left(\mathrm{CF}_{3} \mathrm{COOH}\right)$. As soon as trifluoroacetic acid was added, the color of reaction mixture turned red. The mixture was stirred at room temperature for overnight. The reaction mixture was evaporated at reduced pressure. The crude mixture was dissolved in chloroform and washed with water three times. Organic layer was dried over $\mathrm{MgSO}_{4}$ and filtered. The filtrate was evaporated to dryness and the compound M4 was further dried in vacuo and solidified to white-yellow waxy powder (yield: $2.57 \mathrm{~g}, 74 \%$ ). ${ }^{1} \mathrm{H}-\mathrm{NMR}\left(500 \mathrm{MHz}, \mathrm{CDCl}_{3}\right.$ ): $\delta /$ ppm 9.8 (broad s, 2H, -COOH), 7.22 (s, 2H, aromatic), 4.15 (t, $4 \mathrm{H},-\mathrm{OCH}_{2}$ ), 3.83 (t. $4 \mathrm{H},-\mathrm{OCH}_{2^{-}}$), 3.81-3.50 (m, 20H, $-\mathrm{OCH}_{2^{-}}$), 2.60 (t, $\left.4 \mathrm{H},-\mathrm{CH}_{2} \mathrm{COOH}\right) .{ }^{13} \mathrm{C}-\mathrm{NMR}(125 \mathrm{MHz}, \mathrm{CDCl} 3): \delta / \mathrm{ppm}$ 35.2, 66.7, 69.8, 70.5, 70.7, 70.8, 70.9, 71.32, 86.6, 123.6, 153.3, 175.4. MS (Voltage ESI-): calculated $\mathrm{m} / \mathrm{z}$ of $[\mathrm{M}-\mathrm{H}]$ 769.0218; measured $\mathrm{m} / \mathrm{z} 769.0221$.

Polymer synthesis P1: M1 (65 mg, $0.14 \mathrm{mmol}$ ) and M5 (90 mg, $0.14 \mathrm{mmol}$ ) were placed into a Schlenck flask $(50 \mathrm{~mL})$. Toluene $(1.5 \mathrm{~mL})$ and diisopropylamine $(3 \mathrm{~mL})$ were added. After complete dissolution of two monomers, the solution was degassed by three times of vacuum and argon purging. In a separate Schlenck flask, tetrakistriphenylphosphine palladium (0) and copper (I) iodide were dissolved in toluene $(1.5 \mathrm{~mL})$ under a nitrogen atmosphere in a glove box and degassed. The degassed solution containing catalyst was cannulated onto the monomer solution. After transfer of the catalysis solution to monomer solution, polymerization solution was finally degassed again and allowed to stir under argon purging at $55^{\circ} \mathrm{C}$ for 2 days. The reaction mixture filtered with 0.45 micrometer membrane syringe. The toluene solution was precipitated in methanol 2 times. For deprotection of ethylhexyl group of carboxylic group, the collected fluorescent yellow precipitate was redissolved in $100 \mathrm{~mL}$ of tetrahydrofuran (THF) and $1 \mathrm{~m}$ of $\mathrm{NaOH}(100 \mathrm{~mL})$ was added. The solution was stirred overnight at $35^{\circ} \mathrm{C}$. THF was evaporated at the reduced pressure, filtered and the water solution was dialyzed against deionized water for 3 days (membrane MW cut off: 12 000-14 000 gmol$^{-1}, 10 \times 4 \mathrm{~L}$ water exchanges). The polymer solution was lyophilized to yield a yellow solid (74 mg, 80\%). ${ }^{1} \mathrm{H}-\mathrm{NMR}\left(500 \mathrm{MHz}, \mathrm{D}_{2} \mathrm{O}\right): \delta / \mathrm{ppm}$ 7.60 (s, 2H, aromatic), 7.11 (s, $2 \mathrm{H}$, aromatic), 4.13 (broad t, $4 \mathrm{H}$, $-\mathrm{OCH}_{2}-$ ), 3.90-3.30 (broad m, 2OH, $-\mathrm{OCH}_{2} \mathrm{CH}_{2}$ ), 3.15 (s, $6 \mathrm{H}$, $-\mathrm{OCH}_{3}$ ), Molecular weight based on PS-GPC in THF before hydrolysis of ethylhexylgroup $M_{\mathrm{n}}=163700, M_{\mathrm{w}}=624600$, PDI $=3.82$.

P2: Except M6 $(85 \mathrm{mg}, 95.4 \mu \mathrm{mol})$ instead of M5, the polymerization step was followed by synthetic route of $\mathbf{P} 1$ above. After polymerization, polymer solution was centrifuged to get the supernatant $(3500 \mathrm{rpm})$. The supernatant solution was evaporated and redissolved in $10 \mathrm{~mL}$ tetrahydrofuran and $10 \mathrm{~mL}$ of $1 \mathrm{~m} \mathrm{NaOH}$ solution. The solution was stirred overnight at $35{ }^{\circ} \mathrm{C}$ and evaporated at reduced pressure. The solution was dissolved in deionized water and centrifuged to remove the impurity insoluble to water. The water solution was dialyzed against deionized water for 3 days. Centrifugation was again 
conducted to get supernatant after dialysis. The polymer solution was lyophilized to yield a yellow solid (91 mg, 87\%). ${ }^{1} \mathrm{H}$ NMR (500 MHz, $\mathrm{D}_{2} \mathrm{O}$ ): $\delta / \mathrm{ppm} 7.58$ (s, 2H, aromatic), 7.12 (s, $2 \mathrm{H}$, aromatic), 4.13 (m, $2 \mathrm{H},-\mathrm{OCH}-), 3.80-3.20$ (broad $\mathrm{m}, 56 \mathrm{H}$, $\left.-\mathrm{OCH}_{2}-\right), 3.11\left(\mathrm{~s}, 12 \mathrm{H},-\mathrm{OCH}_{3}\right)$. GPC-based molecular weight before the cleavage of protection group, $M_{\mathrm{n}}=32,100 \mathrm{gmol}^{-1}$, $M_{\mathrm{w}}=105,900 \mathrm{gmol}^{-1}$, PDI $=3.3$.

P3: A general procedure about polymerization is identical to the method for P1. Monomer M2 $(40.8 \mathrm{mg}, 69.1 \mu \mathrm{mol})$, monomer M6 (61.6 mg, $69.1 \mu \mathrm{mol})$, toluene $(1.0 \mathrm{~mL})$, and diisopropylamine $(2 \mathrm{~mL})$ are placed into a $50 \mathrm{~mL}$ of Schlenck flask. After complete dissolution of two monomers, the solution was degassed by three times of vacuum and argon purging. In a separate Schlenck flask, tetrakistriphenylphosphine palladium (0) ( 5 mol\% of the monomer) and copper (I) iodide $(5 \mathrm{~mol} \%$ of the monomer) were transferred under a nitrogen atmosphere of a glove box and argon was purged in the Schlenck flask for $10 \mathrm{~min}$. Two catalysts were dissolved in toluene $(1.0 \mathrm{~mL})$ and degassed by three times of vacuum and argon purging. The degassed solution containing catalyst was cannulated onto monomer solution. After transfer of the catalyst solution to monomer solution, three cycles of degassing to a polymer solution was finally done again. The polymer solution was allowed to stir under argon purging at $55{ }^{\circ} \mathrm{C}$ for 2 days. The reaction mixture was filtered with 0.45 micrometer membrane syringe. The mixture solution was concentrated at reduced pressure and precipitated in diethylether $(15 \mathrm{~mL})$. The crude polymer was redissolved in $15 \mathrm{~mL}$ of dioxane and the solution was mixed with $10 \%$ aqueous $\mathrm{NaOH}$ solution $(15 \mathrm{~mL})$. Solution was stirred under argon atmosphere at room temperature for $12 \mathrm{~h}$. Polymer solution was centrifuged and dialyzed against deionized water for 2 days $(10 \times 4 \mathrm{~L}$ water exchanges). The polymer solution was lyophilized to yield a yellow solid (51 mg, 60\%). ${ }^{1} \mathrm{H}-\mathrm{NMR}\left(500 \mathrm{MHz}, \mathrm{D}_{2} \mathrm{O}\right.$ ): $\delta / \mathrm{ppm}$ 7.27 (s, 2H, aromatic), 7.15 (s, $2 \mathrm{H}$, aromatic), 4.03 (broad $\mathrm{m}, 6 \mathrm{H}$, $-\mathrm{CH}_{2} \mathrm{CH}_{2} \mathrm{O}-$-, -OCH-), 3.81-3.21 (broad m, $56 \mathrm{H},-\mathrm{OCH}_{2} \mathrm{CH}_{2}$ ), 3.18 (broad s, $12 \mathrm{H},-\mathrm{OCH}_{3}$ ), 2.25 (broad t, 4H, - $\mathrm{CH}_{2} \mathrm{CH}_{2} \mathrm{COO}-$ ), 1.87 (broad $\mathrm{m}, 4 \mathrm{H},-\mathrm{CH}_{2} \mathrm{CH}_{2} \mathrm{CH}_{2}-$ ), GPC (THF) based $M_{\mathrm{n}}=73,100$ $\mathrm{gmol}^{-1}, M_{\mathrm{w}}=214,200 \mathrm{gmol}^{-1}, \mathrm{PDI}=2.93$.

P4: Except M3 $(41.85 \mathrm{mg}, 62 \mu \mathrm{mol})$ instead of M2, the polymerization step was conducted by synthetic route of P3 above. After the polymerization, polymer mixture was centrifuged to get the supernatant $(3500 \mathrm{rpm})$. The supernatant solution was concentrated at reduced pressure, precipitated in ether, and washed with acetone. The polymer was redissolved in $10 \mathrm{~mL}$ tetrahydrofuran and $10 \mathrm{~mL}$ of $1 \mathrm{~m}$ sodium hydroxide solution. The solution was stirred overnight at $35^{\circ} \mathrm{C}$ and evaporated at reduced pressure. The solution was dissolved in DI water and centrifuged to remove the unknown impurity. The water solution was dialyzed against deionized water for 3 days. During the dialysis, fibril type aggregations observed due to the hydrophobic long alkyl chain and the protonation of carboxylic group. The polymer solution was lyophilized to yield a yellow solid (46 mg, 57\%). A solid P4, of which a carboxylic group is protonated, was completely soluble in water $(\mathrm{pH}=8) .{ }^{1} \mathrm{H}$ NMR (500 MHz, $\mathrm{D}_{2} \mathrm{O}$ ): $\delta / \mathrm{ppm} 7.01$ (s, 2H, aromatic), 6.75 (s, $2 \mathrm{H}$, aromatic), 4.41 (m, 2H, - OCH-), 3.95 (t, 4H, $\left.-\mathrm{OCH}_{2}-\right)$, 3.803.23 (broad m, 56H, - $\mathrm{OCH}_{2}$ ), 3.15 (s, $\left.12 \mathrm{H},-\mathrm{OCH}_{3}\right), 2.05$ (t, 4H, $-\mathrm{CH}_{2} \mathrm{COO}-$ ), 1.78-1.10 (broad m, 16H, - $\mathrm{CH}_{2-}$ ), GPC (THF) based $M_{\mathrm{n}}=19200 \mathrm{gmol}^{-1}, M_{\mathrm{w}}=57800 \mathrm{gmol}^{-1}, \mathrm{PDI}=3.01$.
P5: M4 (60.6 mg, $78.7 \mu \mathrm{mol})$ and M6 (73.6 mg, $82.6 \mu \mathrm{mol})$ were placed into a $50 \mathrm{~mL}$ of Schlenck flask and DMF $(2 \mathrm{~mL})$ and diisopropylamine $(1 \mathrm{~mL})$ were added to the reaction vessel. After complete dissolution of two monomers, the solution was degassed by three times of vacuum and argon purging. In a separate Schlenck flask, tetrakistriphenylphosphine palladium(0) (1 mol\% of the monomer) and copper(I) iodide ( $1 \mathrm{~mol} \%$ of the monomer) were transferred under a nitrogen atmosphere of a glove box and argon was purged in the Schlenck flask for $10 \mathrm{~min}$. Two catalysts were dissolved in morpholine $(1 \mathrm{~mL})$ and degassed by three times of vacuum and argon purging. The degassed solution containing catalyst was cannulated onto monomer solution. After transfer of the catalyst solution to monomer solution, three cycles of degassing to a polymer solution was finally done again. The polymer solution was allowed to stir under argon purging at $55{ }^{\circ} \mathrm{C}$ for 2 days. The solvent was evaporated to dryness. The crude polymer was redissolved in $50 \mathrm{~mL}$ of $1 \mathrm{~m}$ sodium hydroxide solution and stirred under argon atmosphere at room temperature for $1 \mathrm{~h}$. Polymer solution was centrifuged and the supernatant was dialyzed against deionized water for 2 days $(10 \times 4 \mathrm{~L}$ water exchanges $)$. The polymer solution was lyophilized to yield a yellow waxy solid (77 mg, 67\%). ${ }^{1} \mathrm{H}-\mathrm{NMR}$ (500 MHz, $\mathrm{D}_{2} \mathrm{O}$ ): $\delta / \mathrm{ppm} 8.30$ (broad s, $\left.2 \mathrm{H},-\mathrm{COOH}\right), 7.25$ (s, 2H, aromatic), 7.09 (s, $2 \mathrm{H}$, aromatic), 4.16 (t, 4H, $-\mathrm{OCH}_{2^{-}}$), 4.08 (m, 2H, -OCH-), 3.8-3.2 (broad $\mathrm{m}, 80 \mathrm{H},-\mathrm{OCH}_{2} \mathrm{CH}_{2} \mathrm{O}$ ), $3.15\left(\mathrm{~s}, 12 \mathrm{H},-\mathrm{OCH}_{3}\right), 2.27$ (s, 4H, - $\left.\mathrm{CH}_{2} \mathrm{COO}-\right)$, molecular weight; $M_{\mathrm{n}}$ by ${ }^{1} \mathrm{H}-\mathrm{NMR}$ end analysis $=14200$.

P5-A: End-capping reaction was conducted in-situ after polymerization of P5 was finished. 4-ethynylbenzoic acid (11 $\mathrm{mg}, 79 \mu \mathrm{mol})$ as an end-capper was dissolved in DMF $(0.5 \mathrm{~mL})$ and DIPA (0.2 mL). End-capper solution was degassed and cannulated onto polymer solution. A trace amount of palladium catalyst and cupper iodide in DMF $(0.5 \mathrm{~mL})$ degassed by vacuum and argon purging recycles was also added to polymer solutions. The polymer solution was allowed to stir under argon purging at $55^{\circ} \mathrm{C}$ for an additional $24 \mathrm{~h}$. After the reaction, a work-up procedure for polymer recovery was same as P5. Two new peaks at ${ }^{1} \mathrm{H}-\mathrm{NMR}$ analysis emerged at 7.78, $7.51 \mathrm{ppm}$ corresponding to the aromatic protons of the endcapper, confirming that the carboxylic group was chemically attached.

\subsection{Discussion for Synthesis of Monomers and Polymers}

Synthetic routes for the preparation of all monomers and CPEs are described in Schemes 1 and 2. All polymers were prepared by the palladium-catalyzed Sonogashira-Hagihara copolymerization method. At first, we tried polymerization with a diiodophenyl unit having unprotected free carboxylic acid. However, reactions were not successful because the carboxylic group in the ortho-position caused a side reaction during the polymerization and resulted in a low molecular weight. ${ }^{[61-63]} \mathbf{P 1}$ and P2 were prepared by the copolymerization of a diiodophenyl monomer having carboxylic groups protected with ethylhexyl side chains. After the polymerization, the ethylhexyl group was hydrolyzed by base treatment to give a negatively charged carboxylate ion as a side chain to the polymer structure. A flexible 


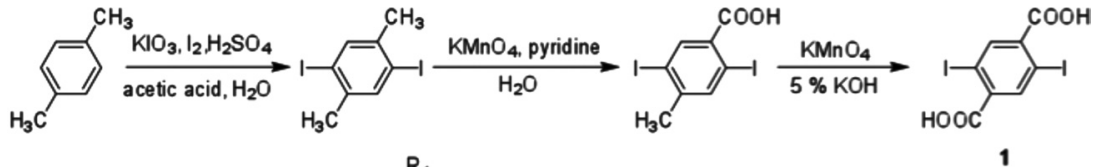

$\underset{\text { 2oluene }}{\stackrel{\text { 2-ethyl-1-hexanol, } \mathrm{H}_{2} \mathrm{SO}_{4}}{\longrightarrow}}$
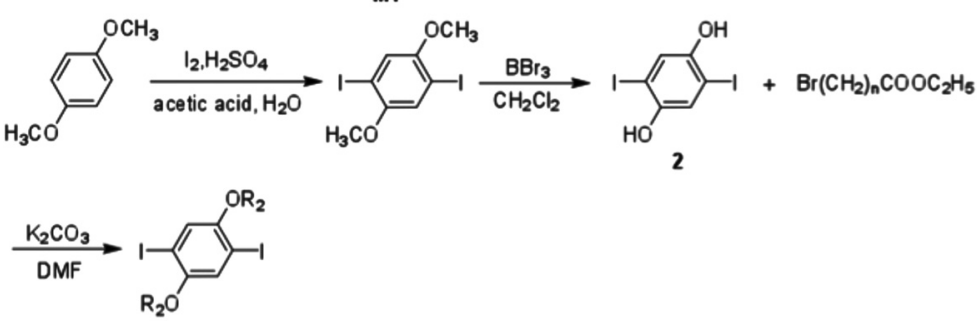

M2 $(n=3)$ or $M 3$ (n=6)
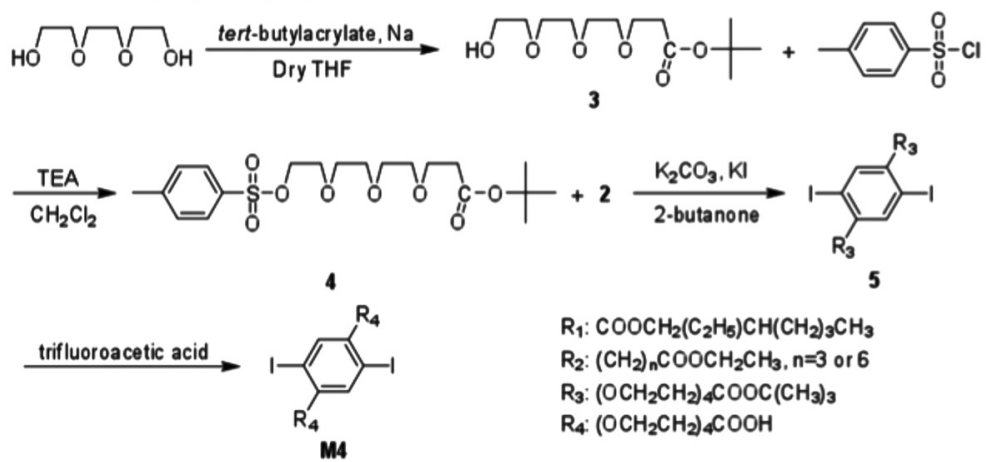

$2 \underset{2 \text {-butanone }}{\stackrel{\mathrm{K}_{2} \mathrm{CO}_{3} \mathrm{Kl}}{\longrightarrow}}$

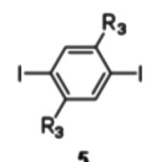

$\mathrm{R}_{1}: \mathrm{COOCH}_{2}\left(\mathrm{C}_{2} \mathrm{H}_{5}\right) \mathrm{CH}\left(\mathrm{CH}_{2}\right)_{3} \mathrm{CH}_{3}$

$\mathrm{R}_{2}:\left(\mathrm{CH}_{2}\right)_{n} \mathrm{COOCH}_{2} \mathrm{CH}_{3}, \mathrm{n}=3$ or 6

$\mathrm{R}_{3}:\left(\mathrm{OCH}_{2} \mathrm{CH}_{2}\right)_{4} \mathrm{COOC}\left(\mathrm{CH}_{3}\right)_{3}$

$\mathbf{R}_{4}:\left(\mathrm{OCH}_{2} \mathrm{CH}_{2}\right)_{4} \mathrm{COOH}$

Scheme 1. Synthesis of Monomers M1 to M4.

and hydrophilic ethylene oxide unit was also introduced in order to give good water solubility to the hydrophobic polymer backbone by suppressing the hydrophobic aggregation. P3 and P4 were also prepared by the polymerization of a diiodo monomer having ethyl-protected carboxylic groups to avoid the solubility problem of the free carboxylic acid group in organic solvents. Representative physical and photophysical data of the CPEs described in this contribution are summarized in Table 1. All CPEs were dissolved in water and showed blue-green emission having the emission $\lambda_{\max }$ of about $460 \mathrm{~nm}$.

\subsection{P1: Conventional CPE Design with lonic and Non-Ionic Water-Soluble Side Chains}

P1 is designed to have alternating ionic and non-ionic water-soluble side chains. This molecular design strategy has been conventionally used to make water-soluble CPEs in the literature. The precursor polymer of P1 before the deprotection of the carboxylic acid group showed a well-defined 0-0 emission band at $487 \mathrm{~nm}$ and the quantum yield of $45 \%$ in chloroform (Figure 2). However, emission of $\mathbf{P 1}$ in water after the deprotection
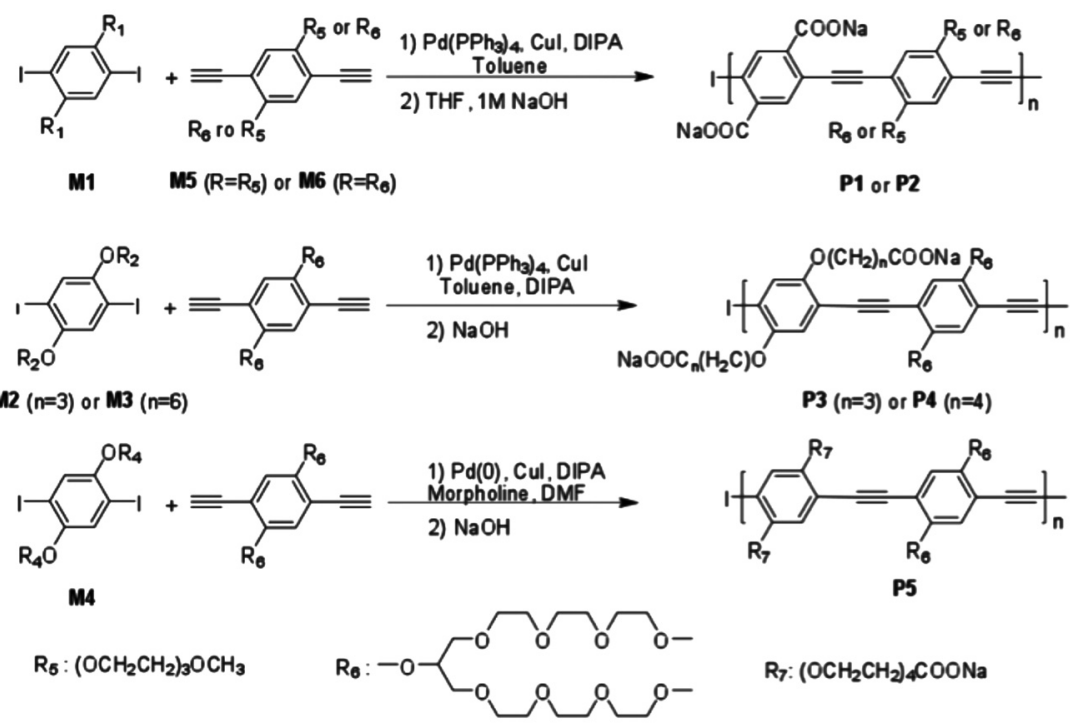

R7: $\left(\mathrm{OCH}_{2} \mathrm{CH}_{2}\right)_{4} \mathrm{COONa}$

Scheme 2. Polymer synthesis (P1-P5). 
Table 1. Physical properties of all polymers used in this study.

\begin{tabular}{|c|c|c|c|c|c|c|}
\hline poly & $\mathrm{M}_{\mathrm{n}} / \mathrm{gmol}^{-1 \mathrm{a})}$ & $\mathrm{DP}^{\mathrm{b})}$ & $\lambda_{\max , a b s / n m} \lambda_{m a x, e m / n m}$ & Stokes shift $\mathrm{cm}^{-1 \mathrm{c})}$ & $E_{\mathrm{g}} / \mathrm{eV}^{\mathrm{d})}$ & $\Phi_{\mathrm{F}}\left(\%, \mathrm{D}_{2} \mathrm{O}\right)^{\mathrm{e})}$ \\
\hline \multirow[t]{2}{*}{ P1 } & 163,700 & 194 & 384 & 4110 & 2.14 & $0.45 \pm 0.49$ \\
\hline & & & 456 & & & \\
\hline \multirow[t]{2}{*}{ P2 } & 32,100 & 29 & 368 & 5430 & 2.18 & $0.09 \pm 0.02$ \\
\hline & & & 460 & & & \\
\hline \multirow[t]{2}{*}{ P3 } & 73,100 & 59 & 421 & 2150 & 2.54 & $31.6 \pm 5.50$ \\
\hline & & & 463 & & & \\
\hline \multirow[t]{2}{*}{ P4 } & 19,200 & 15 & 406 & 3080 & 2.52 & $5.3 \pm 0.55$ \\
\hline & & & 464 & & & \\
\hline \multirow[t]{2}{*}{ P5 (or P5-A) } & 14,200 & 10 & 412 & 2390 & 2.64 & $51.4 \pm 9.55(36.6 \pm 4.37)$ \\
\hline & & & 457 & & & \\
\hline
\end{tabular}

a) Molecular weight of all polymers except P5 was measured by GPC before hydrolysis of the ethylhexyl protection. $M_{n}$ for P5 was done by ${ }^{1} \mathrm{H}-\mathrm{NMR}$ end analysis in

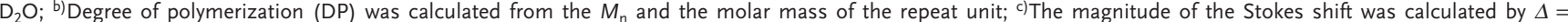

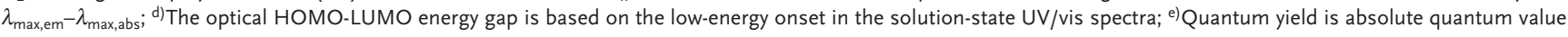
measured by using an integrating sphere, polymer concentration: $1 \mathrm{mg} / \mathrm{L}$.

effectively dissembles $\mathbf{P 1}$ aggregates. Considering the fact that P1 is a negatively charged CPE, cationic surfactants should be more effective than nonionic and anionic surfactants. Note that
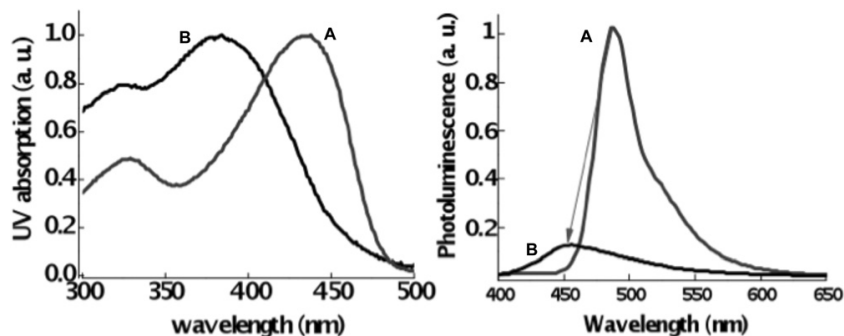

Figure 2. UV and Photoluminescence spectra of P1 before (A, in chloroform) and after $(B$, in water) the cleavage of the ethylhexyl protecting group $\left(\mathrm{P} 1\right.$ conc. $\left.=5 \mathrm{mgl}^{-1}\right)$.

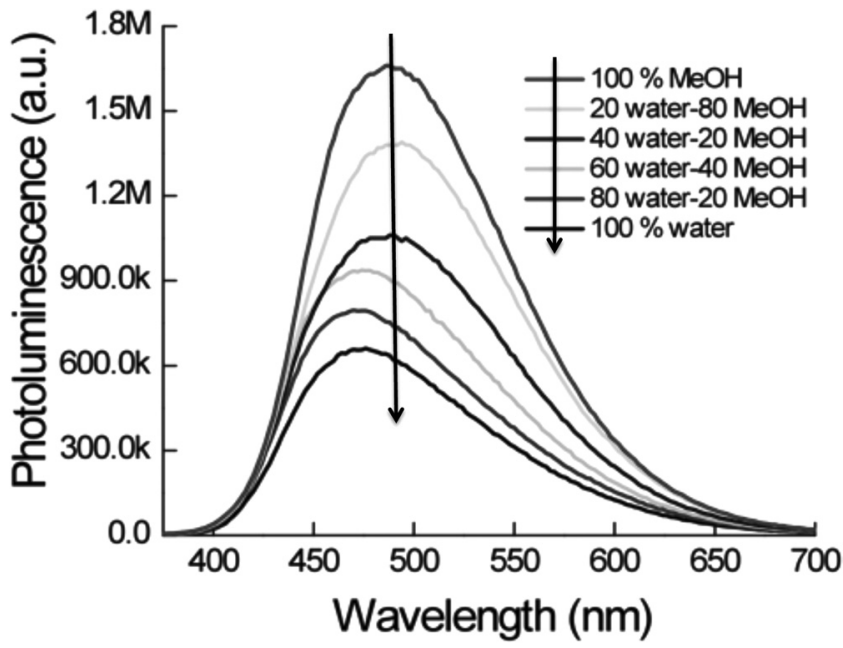

Figure 3. Photoluminescence spectra of P1 in various water/methanol mixture solvents ( $\mathrm{P1}$ conc. $=0.7 \mathrm{mgml}^{-1}$, excitation wavelength: $365 \mathrm{~nm}$ ). the increase in the fluorescence intensity of $\mathbf{P 1}$ with increasing concentration of added DTAB was most significant between $0.1 \mathrm{wt} \%$ of DTAB and $0.5 \mathrm{wt} \%$ of DTAB. Interestingly, our calculation showed that $0.4 \mathrm{wt} \%$ of DTAB is required to make $1: 1$ charge complex with carboxylic acid groups of P1 as schematically illustrated in Figure 5. ${ }^{[69]}$ Distinct $0-0$ and $0-1$ emission bands are observed in Figure 4(c) indicating that DTAB effectively dissembles the $\mathbf{P} 1$ aggregates. ${ }^{[48,53]}$

We investigated CPE aggregation in an aqueous environment by means of various electron microscopic techniques. ${ }^{[70-74]}$ Conventional TEM microscopy images of P1 shown in Figure 6a revealed tree-like, fractal aggregation suggesting that P1 was completely aggregated. The magnified transition region shows that rigid rod-like P1 chains aggregated to form cylindrical aggregates. A few single P1 chains could aggregate into a fibril by hydrophobic $\pi-\pi$ stacking and several fibrils could agglomerate to form few tens of nanometers wide fibers. However, this aggregated feature might be developed during the drying process for the conventional TEM sample preparation rather than representing the packing of $\mathbf{P 1}$ in water. Therefore, we additionally conducted cryogenic TEM to observe an actual morphology of P1 in aqueous environment. A P1 solution in water was rapidly quenched in liquid ethane using cryo-plunge and images were obtained as a vitrified state below $-170{ }^{\circ} \mathrm{C}$. Interestingly, we observed a self-assembled sheet-like structure of P1 from the cryo-images (Figure 6b). Hydrophobic interaction between the rigid-rod polymer chains likely induces the molecular packing and thin layer formation, followed by aggregation formation as schematically suggested in Figure 6c. We believed that the initially charged carboxylic acid group of P1 was gradually protonated during the prolonged dialysis to remove oligomers and excess ions, accelerating the polymer aggregation as well. Therefore, even though P1 was modified with water-soluble ionic and non-ionic side chains, P1 molecules aggregate due to the rigidity and the hydrophobic nature of the main chain, resulting in the extremely low quantum yield of 0.45 in water. 

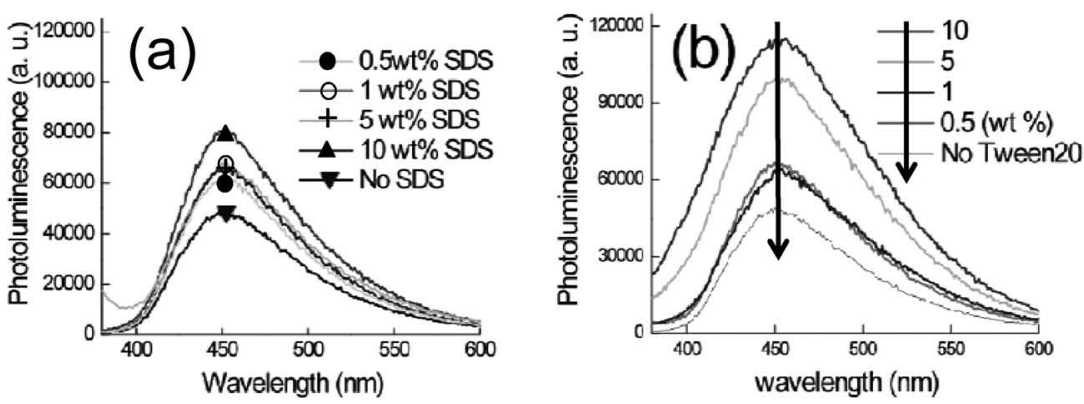

www.MaterialsViews.com

Figure 4. Photoluminescence profile of P1 in water by adding different types of surfactants; a) SDS, negative, b) tween20, neutral, c) DTAB, positive (P1 conc. $=5 \mathrm{mgml}^{-1}$ ).

\subsection{P2: Preventing Aggregation by the Bulky Bifurcated Ethylene Oxide Side Chains}

We replaced the single strand ethylene oxide side chains of P1 with the bulky bifurcated ethylene oxide chain and prepared P2 to efficiently sheath the rigid hydrophobic CPE backbone and minimize the $\pi-\pi$ stacking (Figure 1$) \cdot{ }^{[33,60]}$ Initially, we measured the molecular weight of $\mathbf{P 2}$ by DMF-based GPC after the cleavage of the carboxy-protecting group. However, the molecular weight of $\mathbf{P 2}$ was measured up to a few millions $\left(\mathrm{gmol}^{-1}\right.$ ) likely due to an incorrectly exaggerated hydrodynamic volume of the polymer caused by the limited solubility and aggregation of P2 in DMF. The molecular weight of P2 before the cleavage of the protection group measured by GPC was 32,100 . The absorption and emission spectra of $\mathbf{P} 2$ in water are presented in Figure 7. We examined the effect of the bulky ethylene oxide side chains in molecular aggregation by TEM and found that there was no large aggregation like the one found from P1 even though P2 solution was dried during the conventional TEM sample preparation. Instead, spherical particles of a few tens of nanometers in size were observed, suggesting that aggregation of CPE was efficiently suppressed by the bulky nonionic ethylene oxide side chains. ${ }^{[3,60]}$ However, surprisingly even the non-aggregated P2 in aqueous solution showed very low quantum yield of $0.9 \%$
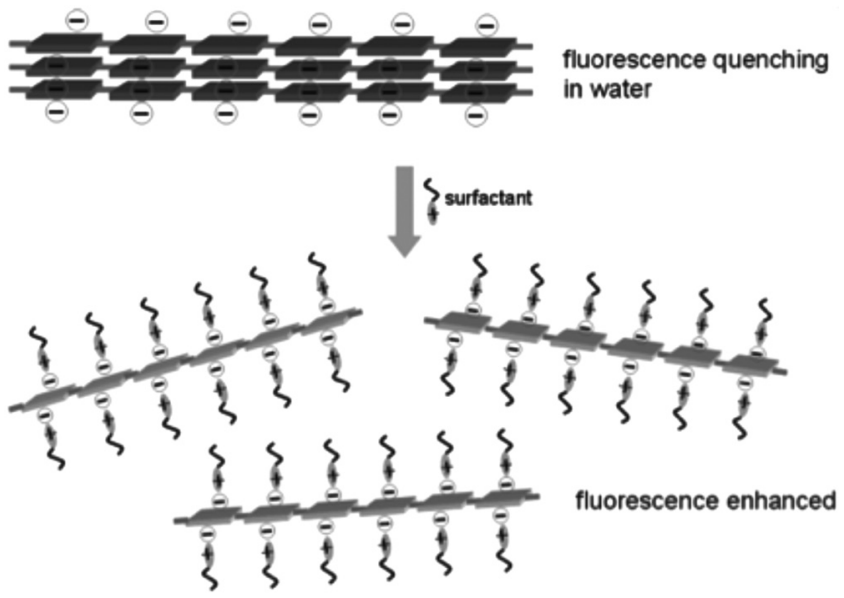

Figure 5. Schematic illustration of surfactant effect on P1 in water. while the $\mathbf{P} 2$ derivative having the ethyl protected carboxylic acid side chains has $55.0 \%$ quantum yield in chloroform. Ionicpendant groups having the sodium counter ions directly attached to the CPE backbone is hypothesized to be closely related with photoluminescence quenching of CPE in water. As supporting evidence, we found enhancement of emission intensity of $\mathbf{P 1}$ and $\mathbf{P 2}$ in an acidic condition where the carboxylic group should be protonated. It is believed that the observed quenching is attributed to the photoinduced electron transfer quenching mechanism as a result of the formation of electron donor/acceptor charge transfer complex between the polymer backbone and the directly connected ionic side chain. ${ }^{[75,76]}$

\subsection{P3 and P4: Spacer Between the CPE Backbone and the lonic Moiety}

We put an alkyl spacer between the CPE backbone and the ionic pendant groups and prepared P3 to exam the hypothesis that the direct connection of the ionic pendant group to the CPE backbone causes the emission quenching. Figure 8 illustrates the absorption and the emission spectra of P3. The emission spectrum of P3 shows a well-defined 0-0 band at the $\lambda_{\max }$ of $463 \mathrm{~nm}$. As we expected, the aqueous solution of P3 has the quantum yield of $31.6 \%\left(1 \mathrm{mgL}^{-1}\right)$ that is dramatically improved from the $0.9 \%$ of the aqueous solution of P2, strongly supporting that the directly attached carboxylic acid groups to P2 backbone cause the quenching. We previously prepared similar PPEs having sulfonate ionic groups via a propyloxy linkage and bifurcated ethylene oxide side chains. The sulfonated version of P3 had a high quantum efficiency of 0.53 showing a good agreement with P3. ${ }^{[11]}$ Conventional TEM microscopy images of $1 \mathrm{wt} \%$ P3 aqueous solution was essentially identical to that of $\mathbf{P} \mathbf{2}$ showing spherical nanoparticles of a few tens of nanometer.

We increased the length of the alkyl spacer from propyl $\left(\mathrm{C}_{3}\right)$ to hexyl $\left(\mathrm{C}_{6}\right)$ and prepared $\mathbf{P} 4$ to test whether a long hydrophobic spacer would cause aggregation of CPE. Accordingly the quantum yield of the aqueous solution of $\mathbf{P} 4$ significantly dropped down to $5.3 \%$. Dialysis purification of P4 also indicated that the longer hexyl hydrophobic chain lowers the solubility of P4 in water. Conventional TEM microscopy images (data not shown) show that P4 having the hexyl spacers are more aggregated in water than P3 due to the long hydrophobic 

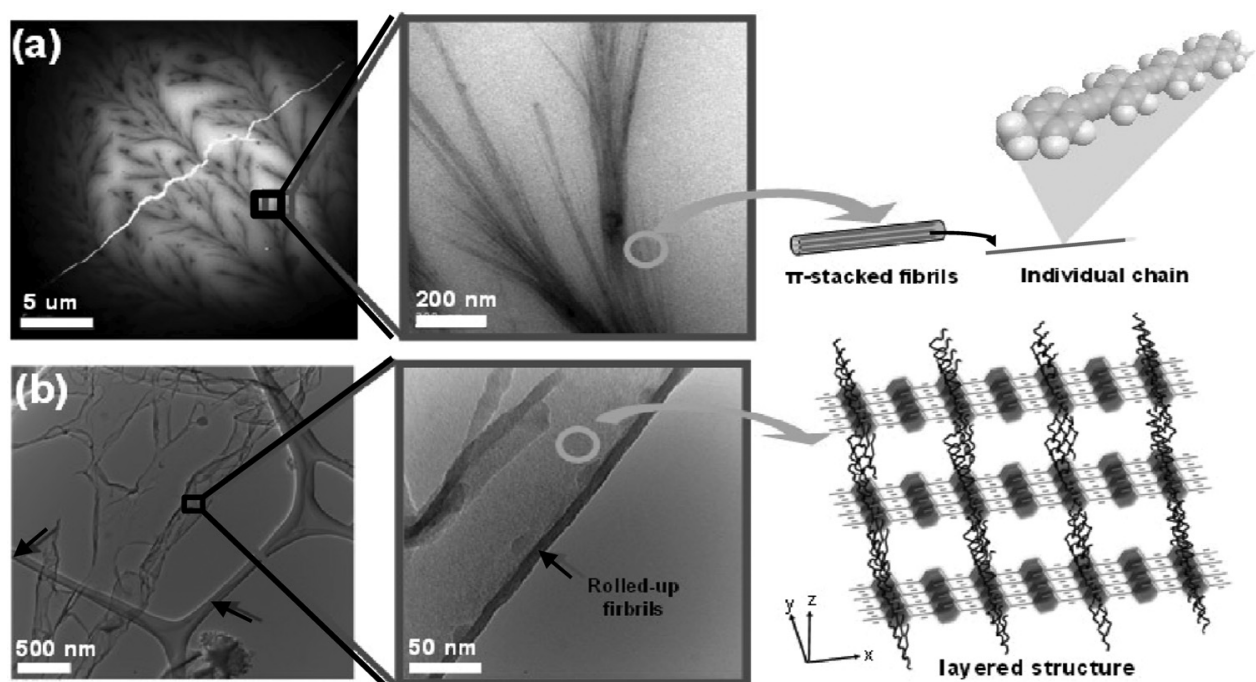

Figure 6. TEM microscopy images of P1 in a) dried state and b) 1 w\% water (arrows represent lacey carbons), c) proposed models for the aggregated structures of P1 in air or water.

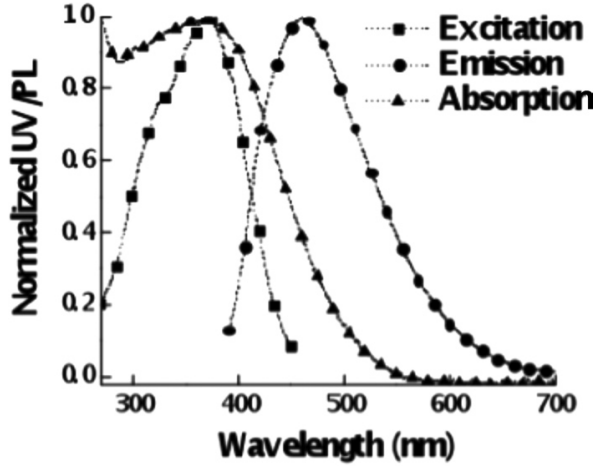

Figure 7. Absorption and Emission spectra of $\mathbf{P 2}\left(10 \mathrm{mgL}^{-1}\right)$ in water (excitation at $365 \mathrm{~nm}$ ), excitation spectra of P2 was obtained corresponding to the emission at $460 \mathrm{~nm}$.

alkyl spacers. ${ }^{[77-84]}$ We hardly observed any significant aggregation during the dialysis of $\mathbf{P 1}, \mathbf{P} 2$ and $\mathbf{P} 3$ in water. Under visual observation, they remained soluble in deionized water and the solubility exceeded approximately $1 \mathrm{mg} \mathrm{mL}^{-1}$. However, protonation of carboxylic group of $\mathbf{P} 4$ during the dialysis induced precipitation of $\mathbf{P} 4$, indicating that the long alkyl spacers reduced the water-solubility of $\mathbf{P} 4$ compared to other CPEs. After producing negative charges to $\mathbf{P} 4$ in phosphate buffer $(\mathrm{pH}=8)$ or in a slightly basic aqueous solution, the solubility of $\mathbf{P 4}$ in water was significantly enhanced.

\subsection{P5: Bulky Anionic Side Chain and Water- Soluble Spacer for the Ionic Side Chain}

We replaced the hydrophobic alkyl linker with a hydrophilic ethylene oxide linker when we synthesized P5 to prevent aggregation of CPE induced by the hydrophobic nature of the alkyl linker unit. P5 completely dissolved in pure

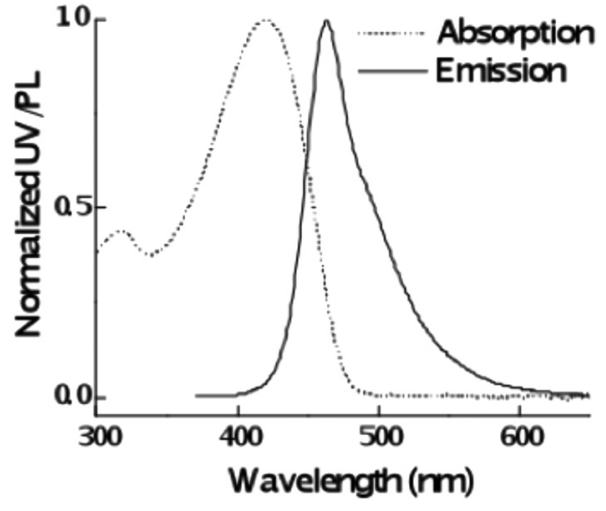

Figure 8. Normalized absorption (dotted) and emission (solid) spectra of P3 (7 $\left.\mathrm{mgL}^{-1}\right)$ in water (excitation at $365 \mathrm{~nm}$ ).

water $(>10 \mathrm{mg} / \mathrm{mL})$ and its solubility was independent to $\mathrm{pH}$ of the aqueous solution. P5 was also soluble in a polar solvent such as dimethyl sulfoxide and methanol and partially soluble in tetrahydrofuran. Photoluminescence spectrum of P5 in Figure 9(a) is narrow with a well-defined $0-0$ band at $457 \mathrm{~nm}$. P5 has the highest fluorescent emission quantum yield of $51.4 \%\left(1 \mathrm{mgL}^{-1}\right)$ among other CPEs and is over 110 times more emissive than P1.
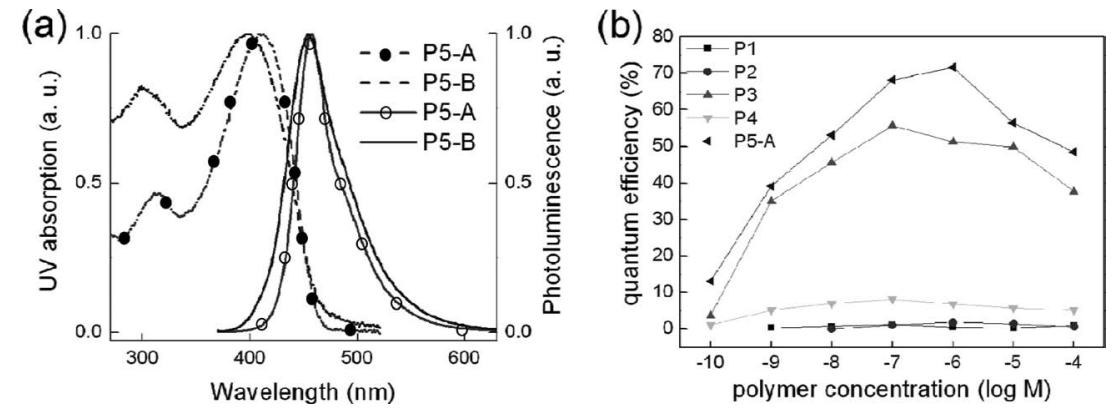

Figure 9. a) UV and PL spectra $\left(5 \mathrm{mgL}^{-1}\right)$ of P5 and P5-A (Polymers were excited at $365 \mathrm{~nm}$ ), b) fluorescence quantum yield of all polymers (P1 to P5) at various concentrations. 

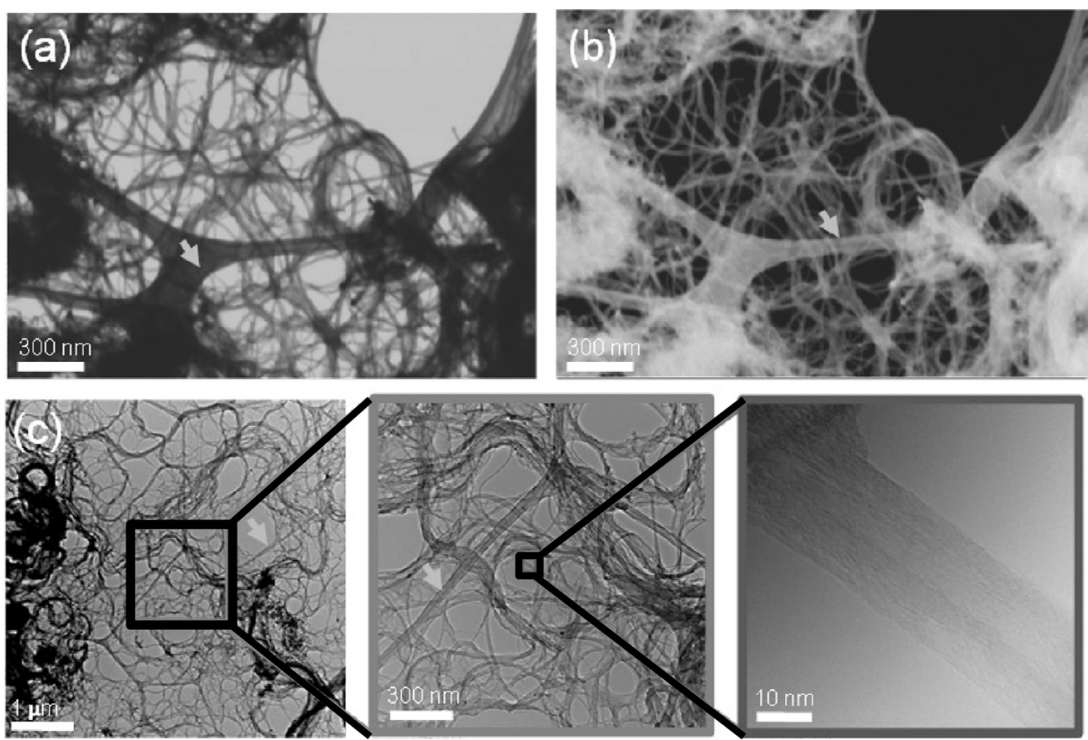

Figure 10. Electron microscopy images of P5; a) SEM (SE2 mode, $30 \mathrm{kV}$ ) and b) transmission mode (STEM) and c) conventional TEM images (200 kV). All samples were prepared with $1 \mathrm{wt} \%$ solution in water on a lacey carbon film (indicated by the arrows in the figures) and dried in air.

Electron microscopic analysis for P5 did not show any significant aggregation, indicating that the hydrophilic nature of the side chain is necessary to prevent CPE aggregation in water. As shown using the scanning transmission electron microscope (STEM) and the conventional TEM (Figure 10), agglomeration of $\mathbf{P} \mathbf{5}$ was noticeably suppressed while $\mathbf{P 1}$ or $\mathbf{P 4}$ showed a micrometer-sized massive aggregation. From the conventional TEM images one can apparently observe fibrils of approximately $25 \mathrm{~nm}$ (Figure 10c). Molecular mechanics calculations carried out using MM2 force field predicted that a hydrophobic backbone of $\mathbf{P 5}$ would be wrapped by the hydrophillic side chains and the resulting thickness of the polymer chain would be $2.4 \mathrm{~nm}$. Therefore, the observed fibrils are likely composed of only a few of polymer chains even after water evaporated slowly during the TEM sample preparation. These results lead to a reasonable conclusion that hardly any $\pi-\pi$ stacking among P5 forms in water. We also additionally carried out cryogenic TEM of P5 in aqueous environment to further investigate the correlation between the nature of the side chain and the aggregation behavior of CPE. A spider web-like entangled structure formed by the rigid rod-like P5 chains shown in Figure $\mathbf{1 1}$ clearly indicates discrete polymer chains without agglomeration throughout the whole area. The thickness of the polymer chain in the cyro-TEM image is about $7 \mathrm{~nm}$, that is, thicker than $2.4 \mathrm{~nm}$ predicted by molecular modeling. The clumps found along the polymer chain in the middle figure are ice crystals formed during the cryo-TEM sample preparation. The cryo-TEM analysis convincingly reveals the non-aggregated morphology of $\mathbf{P 5}$ in water.

We additionally investigated the concentration dependence of the quantum yield of the CPEs. As shown in Figure 9b, the quantum yield of CPEs in water has the same trend of other fluorophores in organic solvents. They mostly show the highest fluorescence efficiency at submicromolar concentration regime and as the concentration increased above that regime the quantum yield decreased showing the concentration dependent selfquenching.

Finally, we prepared P5-A which has two directly-attached carboxylic acid units at the chain ends to investigate further the influence of carboxylic acid group to the emissive property of CPEs. In situ endcapping reaction to $\mathbf{P 5}$ during polymerization was undertaken by adding 4-ethynylbenzoic acid with additional palladium catalyst (Scheme 3). ${ }^{[11,85-87]}$ As shown in Figure 9a, the chain end modification essentially did not cause any spectral broadening nor bathochromic shift, indicating minimal influence on the solubility of P5-A and negligible aggregation of P5-A in water. P5-A indeed showed a similar solubility in water and identical TEM images as P5. However, the quantum yield of P5-A was largely reduced to $31.6 \%$ that is $38.5 \%$ drop from $51.4 \%$ of $\mathbf{P 5}$, clearly demonstrating that a directly-connected ionic group to the conjugated backbone of CPEs has a detrimental effect to the emission property of CPEs. ${ }^{[88]}$

\section{Conclusion}

We systematically investigated the effect of the chemical nature, shape, and the length of the ionic and nonionic side chains on the water solubility and quantum yield of conjugated polyelectrolytes by means of electron microscopy and spectroscopic analysis. Simple ionic and anionic decoration of CPE did not warrant good water-solubility because of the rigid and hydrophobic nature of the conjugated backbone of CPEs. TEM analysis combined with quantum yield measurement reveals that unless CPEs are modified with bulky hydrophilic ethylene oxide side chains, CPEs form aggregates in water and consequent fluorescence quenching. Carboxylic acid group, which is a commonly used and convenient functional group for

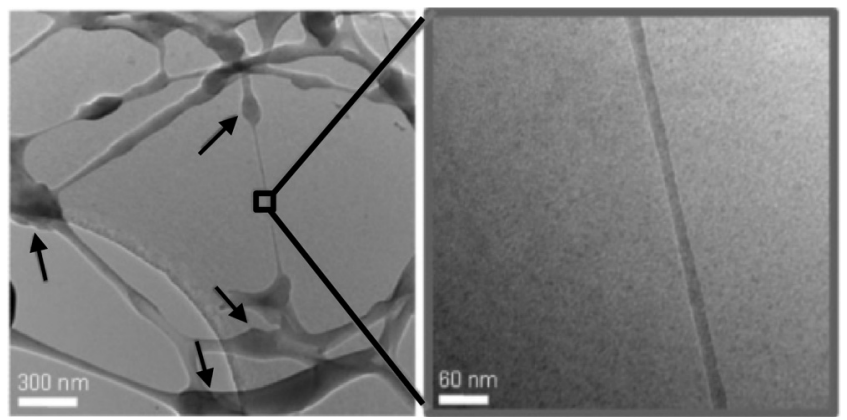

Figure 11. Cryo-TEM images of P5-A (1 wt\% in water, applied voltage: $120 \mathrm{kV}$ ). The sample was prepared with $1 \mathrm{wt} \%$ solution in water on a formvar-coated grid, stabilized with evaporated carbon film. Massive lumps (arrows) in the left figure are ice crystals. 


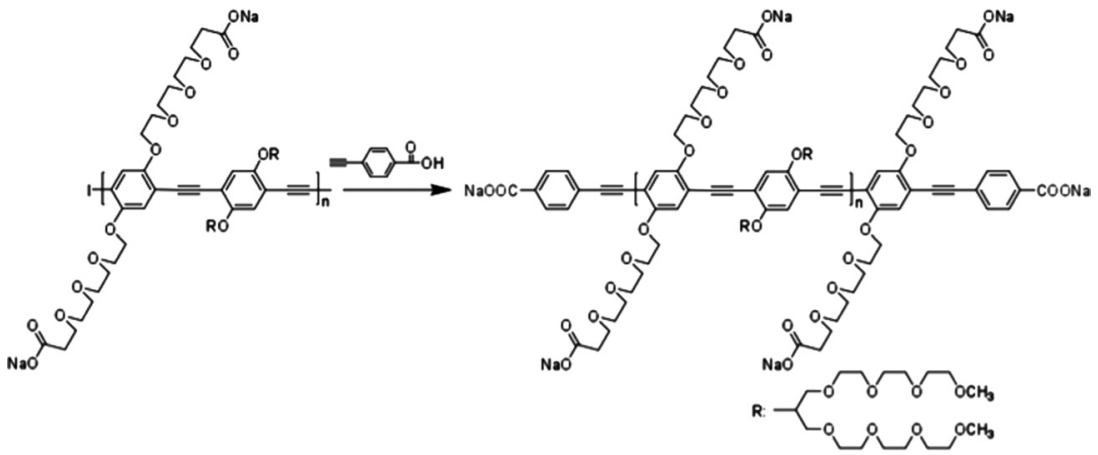

Scheme 3. In situ end-capping reaction for P5-A.

bioconjugation, turned out to have a detrimental influence on the emissive property of CPE when it is connected directly to the CPE backbone. Placing a spacer linker between carboxylic acid and the CPE backbone solved the quenching problem. However, the nature and the length of the spacer group also largely influence on the water-solubility of CPEs. When the alkyl linker was long, the hydrophobic nature of the linker induced self-assembled aggregates. The presented results reveal the effects of the side chain design on the water-solubility and the consequent emissive property of CPEs and provide a molecular design principle to achieve highly emissive, completely watersoluble, and conveniently functionalized CPEs.

\section{Experimental Section}

Materials and Methods: All chemicals were purchased from SigmaAldrich, Inc. or Acros Organics, Inc. and used without further purification. Compounds $1,{ }^{[89,90]} \mathbf{2},,^{[91,92]} \mathbf{M} 5^{[50]}$ and $\mathbf{M} 6^{[50,60,93]}$ in Schemes 1 and 2 are prepared according to the literature published previously. All polymers (P1 to P5 and P5-A) were purified by dialysis against deionized water (molecular weight cut-off: 12,000-14,000 $\mathrm{gmol}^{-1}$ ) for 3 days, lyophilized to dry the polymer, and stored in the dried state at $4{ }^{\circ} \mathrm{C}$. The molecular weight of all CPEs except P5 was determined by GPC with the polystyrene references in THF before the cleavage of the ethylhexyl protecting group of carboxylic acid. Due to the limited solubility of P5 in THF, its numberaveraged molecular weight $\left(M_{n}\right)$ was calculated by ${ }^{1} H N M R$ endgroup analysis. NMR characterization was done with Varian Inova 500 (500 MHz, 11.7 T, Tin)

Photophysical Experiments: UV/vis absorption spectra of the CPE solutions were obtained on a Cary UV50 UV/Vis spectrometer (Varian, Inc.). Steady-state fluorescence spectra of the CPEs were recorded on a PTI QuantaMaster spectrofluorometer ${ }^{\mathrm{TM}}$. The molar concentration of the CPE solutions was determined based on the repeat unit of the CPEs. Corrected fluorescence spectra were obtained for variations in photomultiplier response over wavelength using correction curves generated on the instrument. The fluorescence spectra were normalized by the optical density corresponding to the highest fluorescence intensity. The quantum yields of the CPEs in various concentrations were measured by exciting the CPEs at $365 \mathrm{~nm}$ in deionized water using an integrating sphere attached to the PTI QuantaMaster spectrofluorometer.

Electron Microscopy Analysis: A copper TEM grid coated with a 20-30 nm film of pure carbon (purchased from Electron Microscopy Sciences, PA, USA) was held at the tip of a tweezer. A small drop of aqueous CPE solution was placed on the grid to form a bead. An excess samples in water were blotted off by touching the grid with a filter paper and the sample was left for drying. Images were taken in the bright-field mode with a Tecnai G2 12 Twin transmission electron microscope at $120 \mathrm{kV}$ accelerating voltage. Structures were imaged at slight underfocus in order to enhance contrast. Sample preparation for Figure 10 was done in a similar way and SEM and TEM images were respectively obtained using Ultra55 Field Emission Scanning Electron Microscope (FESEM, Zeiss, $30 \mathrm{kV}$ ) and JEOL 2100 TEM (acceleration voltage: $200 \mathrm{kV}$ ). For cryo-TEM images, a carbon coated film on a broken pattern consists of wovenmesh-like holes (300 mesh) or a formvar coated grid, stabilized with evaporated carbon film were purchased from Electron Microscopy Sciences, Inc (PA, USA) and a cryoplunge (Gatan, Inc, CA, USA) was used for polymer sample preparation. The specimen grid was clamped between the tips of plunging tweezers and $3 \mu \mathrm{L}$ of polymer solution (1 w\% or $0.1 \mathrm{wt} \%$ in water) was blotted to grid for production of thin, aqueous film. It is then plunged into a temperature controlled ethane bath $\left(<-170{ }^{\circ} \mathrm{C}\right)$ and polymer solution is rapidly frozen as vitrified ice. Sample was stored in liquid nitrogen until use. The grid was transferred to the TEM for unstained, in situ observation. Images were taken in the bright-field mode with JEOL 2100 transmission electron microscope at $120 \mathrm{kV}$ accelerating voltage.

\section{Acknowledgements}

This work is supported by the National Science Foundation (Career DMR 064486). We greatly thank Professor Darrin Pochan and Tuna Yucel for valuable provisions and discussions of preliminary TEM images.

Received: August 26, 2011

Revised: October 11, 2011

Published online: January 9, 2012

[1] M. Pinto, K. S. Schanze, Synthesis 2002, 9, 1293-1309.

[2] H. Jiang, P. Taranekar, J. R. Reynolds, K. S. Schanze, Angew. Chem. Int. Ed. 2009, 48, 4300-4316.

[3] F. Feng, H. Wang, L. Han, S. Wang, J. Am. Chem. Soc. 2008, 130, 11338-11343.

[4] H. Li, R. Yang, G. C. Bazan, Macromolecules 2008, 41, 1531-1536.

[5] M. Kang, O. K. Nag, R. R. Nayak, S. Hwang, H. Suh, H. Y. Woo, Macromolecules 2009, 42, 2708-2714.

[6] G. C. Bazan, S. Wang, L. Liu, L. An, Angew, Chem. Int. Ed. 2009, 48, 4372-4375.

[7] H.-A. Ho, M. Béra-Abérem, M. Leclerc, Chem. Eur. J. 2005, 11, 1718-1724 and references therein.

[8] K. P. R. Nilsson, O. Inganäs, Nat. Mater. 2003, 2, 419-424.

[9] B. Liu, G. C. Bazan, Chem. Mater. 2004, 16, 4467-4476 and references therein.

[10] C. J. Yang, M. Pinto, K. Schanze, W. Tan, Angew. Chem. Int. Ed. 2005, 44, 2572-2576.

[11] K. Lee, L. K. Povlich, J. Kim, Adv. Funct. Mater. 2007, 17, 2580-2587.

[12] B. Liu, G. C. Bazan, Proc. Natl. Acad. Sci. USA. 2005, 102, 589-593.

[13] K. Lee, J.-M. Rouillard, T. Pham, E. Gulari, J. Kim, Angew. Chem. Int. Ed. 2007, 46, 4667-4670.

[14] C.-C. Pun, K. Lee, H.-J. Kim, J. Kim, Macromolecules. 2006, 39, 7461.

[15] M. B. Abérem, A. Najari, H.-A. Ho, J.-F. Gravel, P. Nobert, D. Boudreau, M. Leclerc, Adv. Mater. 2006, 18, 2703-2707.

[16] D. Yu, Y. Zhang, B. Liu, Macromolecules 2008, 41, 4003-4011.

[17] K.-Y. Pu, B. Liu, Macromolecules 2008, 41, 6636-6640.

[18] F. Feng, Y. Tang, S. Wang, Y. Li, D. Zhu, Angew. Chem. Int. Ed. 2007, 46, 7882-7886.

[19] C. Fan, K. W. Plaxco, A. J. Heeger, J. Am. Chem. Soc. 2002, 124, 5642-5643.

[20] L. Chen, D. W. McBranch, H.-L. Wang, R. Helgeson, F. Wudl, D. G. Whitten, Proc. Natl. Acad. Sci. USA. 1999, 96, 12287-12292.

[21] K. P. R. Nilsson, A. Herland, P. Hammerström, O. Inganäs, Biochemistry 2005, 44, 3718-3724. 
[22] X. Song, H. Wang, J. Shi, J.-W. Park, B. I. Swanson, Chem. Mater. 2002, 14, 2342-2347.

[23] I.-B. Kim, A. Dunkhorst, U. H. F. Bunz, Langmuir 2005, 21, 7985-7989.

[24] S. J. Dwight, B. S. Gaylord, J. W. Hong, G. C. Bazan, J. Am. Chem. Soc. 2004, 126, 16850-16859.

[25] P. Björk, A. Herland, I. G. Scheblykin, O. Inganäs, Nano Lett. 2005, 5, 1948-1953.

[26] R. L. McRae, R. L. Phillips, I. B. Kim, U. H. F. Bunz, C. J. Fahrni, J. Am Chem. Soc. 2008, 130, 7851-7853.

[27] J. H. Moon, W. McDaniel, P. MacLean, L. E. Hancock, Angew, Chem. Int. Ed. 2007, 46, 8223-8225.

[28] K.-Y. Pu, B. Liu, Adv. Funct. Mater. 2011, 21, 3408-3423.

[29] J. S. Wilson, M. J. Frampton, J. J. Michels, L. Sardone, G. Marletta, R. H. Friend, P. Samorí, H. L. Anderson, F. Cacialli, Adv. Mater. 2005, 17, 2659-2663.

[30] J. H. Seo, T.-Q. Nguyen, J. Am. Chem. Soc. 2008, 130, 10042-10043.

[31] J. M. Hodgkiss, G. Tu, S. Albert-Seifried, W. T. S. Huck, R. H. Friend, J. Am. Chem. Soc. 2009, 131, 8913-8921.

[32] W. Ma, P. K. lyer, X. Gong, B. Liu, D. Moses, G. C. Bazan, A. J. Heeger, Adv. Mater. 2005, 17, 274-277.

[33] R. Yang, H. Wu, Y. Cao, G. C. Bazan, J. Am. Chem. Soc. 2006, 128, 14422-14423.

[34] E. Smela, Adv. Mater. 2003, 15, 481-494.

[35] T. M. Swager, Acc. Chem. Res. 1998, 31, 201-207.

[36] D. T. McQuade, A. E. Pullen, T. M. Swager, Chem. Rev. 2000, 100, 2537-2574

[37] C. Tan, E. Atas, J. G. Müller, M. R. Pinto, V. D. Kleiman, K. S. Schanze, J. Am. Chem. Soc. 2004, 126, 13685-13694.

[38] B. S. Harrison, M. B. Ramey, J. R. Reynolds, K. S. Schanze, J. Am. Chem. Soc. 2000, 122, 8561-8562.

[39] S. A. Kushon, K. D. Ley, K. Bradford, R. M. Jones, D. McBranch, D. Whitten, Langmuir 2002, 18, 7245 .

[40] C. Tan, M. R. Pinto, K. S. Schanze, Chem. Commun. 2002, 446-447.

[41] G. D. Joly, L. Geiger, S. E. Kooi, T. M. Swager, Macromolecules 2006, 39, 7175-7177.

[42] M. R. Pinto, B. M. Kristal, K. S. Schanze, Langmuir 2003, 19, 6523-6533

[43] H. Jiang, X. Zhao, K. S. Schanze, Langmuir 2006, 22, 5541-5543.

[44] X. Zhao, H. Hui, K. S. Schanze, Macromolecules 2008, 41, 3422-3428.

[45] K. Lee, L. Povlich, J. Kim, Analyst 2010, 135, 2179-2189.

[46] F. Wang, G. C. Bazan, J. Am. Chem. Soc. 2006, 128, 15786-15792.

[47] S. A. Jenekhe, J. A. Osaheni, Science 1994, 265, 765-768.

[48] J. Kim, T. M. Swager, Nature 2001, 411, 1030-1034.

[49] Y. Q. Wang, A. J. Zappas, J. N. Wilson, I.-B. Kim, K. M. Solntsev, L. M. Tolbert, U. H. F. Bunz, Macromolecules 2008, 41, 1112-1117.

[50] I. B. Kim, R. Phillips, U. H. F. Bunz, Macrmolecules 2007, 40, 5290-5293.

[51] Y. Wang, A. J. Zappas II, J. N. Wilson, I.-B. Kim, K. M. Solntsev, L. M. Tolbert, U. H. F. Bunz, Macromolecules 2008, 41, 1112-1117.

[52] J. H. Wosnick, C. M. Mello, T. M. Swager, J. Am. Chem. Soc. 2005, 127, 3400-3405

[53] K. Lee, J. C. Cho, J. Deheck, J. Kim, Chem. Commun. 2006, 1983-1985.

[54] H.-A. Ho, M. Leclerc, J. Am. Chem. Soc. 2004, 126, 1384-1387.

[55] K. Doré, S. Dubus, H.-A. Ho, I. Lévesque, M. Brunette, G. Corbeil, M. Boissinot, G. Boivin, M. G. Bergeron, D. Doudreau, M. Leclerc, J. Am. Chem. Soc. 2004, 126, 4240-4244.

[56] H. A. Ho, K. Doré, M. Boissinot, M. G. Bergeron, R. M. Tanguay, D. Bourdreau, M. Leclerc, J. Am. Chem. Soc. 2005, 127, 12673-12676.

[57] H.-A. Ho, M. Boissinot, M. G. Bergeron, G. Corbeil, K. Doré, D. Bourdreau, M. Leclerc, Angew. Chem. Int. Ed. 2002, 41, 1548-1551.

[58] I. B. Kim, R. Phillips, U. H. F. Bunz, Macromolecules 2007, 40, 5290-5293.

[59] R. L. Phillips, O. R. Miranda, C.-C. You, V. M. Rotello, U. H. F. Bunz, Angew. Chem. Int. Ed. 2008, 47, 2590-2594.
[60] A. Khan, S. Müller, S. Hecht, Chem. Commun. 2005, 584-586.

[61] H.-Y. Liao, C.-H. Cheng, J. Org. Chem. 1995, 60, 3711-3716.

[62] V. Subramanian, V. R. Batchu, D. Barange, M. Pal, J. Org. Chem. 2005, 70, 4778-4783.

[63] C. Lambert, K. Utimoto, H. Nozaki, Tetrahedron Lett. 1984, 25, 5323-5326.

[64] A. F. Thünemann, Adv. Mater 1999, 11, 127.

[65] J. J. Lavigne, D. L. Broughton, J. N. Wilson, B. Erdogan, U. H. F. Bunz, Macromolecules 2003, 36, 7409-7412.

[66] L. Chen, S. Xu, D. McBranch, D. Whitten, J. Am. Chem. Soc. 2000, 122, 9302-9303.

[67] A. F. Thünemann, D. Ruppelt, Langmuir 2001, 17, 5098-5102.

[68] H. D. Burrows, V. M. M. Lobo, J. Pina, M. L. Ramos, J. Seixas de Melo, A. J. M. Valente, M. J. Tapia, S. Pradhan, U. Scherf, Macromolecules 2004, 37, 7425-7427.

[69] This value is calculated based on the molecular weight of polymer repeat unit $(658.60 \mathrm{~g} / \mathrm{mol})$.

[70] Y. Talmon, Ber. Bunsenges. Phys. Chem. 1996, 100, 364-372.

[71] D. Danino, A. Bernheim-Groswasser, Y. Talmon, Colloids Surf. A 2001, 183-185, 113

[72] Z. Li, E. Kesselman, Y. Talmon, M. A. Hillmyer, T. P. Lodge, Science 2004, 306, 98-101.

[73] D. J. Pochan, L. Pakstis, B. Ozbas, A. P. Nowak, T. J. Deming, Macromolecules 2002, 35, 5358-5360.

[74] M. S. Lamm, K. Rajagopal, J. P. Schneider, D. J. Pochan, J. Am. Chem. Soc. 2005, 127, 16692-16700.

[75] B. Xie, M. Bagui, R. Guo, K. Li, Q. Wang, Z. Peng, J. Poly. Sci. Part A: Polym. Chem. 2007, 45, 5123-5135.

[76] C. B. Murphy, Y. Zhang, T. Troxler, V. Ferry, J. J. Martin, W. E. Jones Jr., J. Phys. Chem. B 2004, 108, 1537-1543.

[77] There is research on $\pi-\pi$ aggregation induced self-assembly of conjugated oligomer/polymers: C. Tan, M. R. Pinto, M. E. Kose, I. Ghiviriga, K. S. Schanze, Adv. Mater. 2004, 16, 1208-1211.

[78] J. S. Moore, Acc. Chem. Res. 1997, 30, 402-413.

[79] J. C. Nelson, J. G. Saven, J. S. Moore, P. G. Wolynes, Science 1997, 277, 1793-1796.

[80] L. Brunsveld, B. J. B. Folmer, E. W. Meijer, Chem. Rev. 2001, 101, 4071-4097.

[81] L. M. Herz, C. Daniel, C. Silva, F. J. M. Hoeben, A. P. H. J. Schenning, E. W. Meijer, R. H. Friend, R. T. Phillips, Phys. Rev. B 2003, 68, 045203.

[82] J. N. Wilson, W. Steffen, T. G. McKenzie, G. Lieser, M. Oda, D. Neher, U. H. F. Bunz, J. Am. Chem. Soc. 2002, 124, 6830-6831.

[83] W. Steffen, B. Köhler, M. Altmann, U. Scherf, K. Stitzer, U. H. F. Loye, H.-C. Z. Bunz, Chem. Eur. J. 2001, 7, 117.

[84] U. H. F. Bunz, V. Enkelmann, L. Kloppenburg, D. Jones, K. D. Shimizu, J. B. Claridge, H.-C. Z. Loye, G. Lieser, Chem. Mater. 1999, 11, 1416.

[85] P. Samorí, N. Severin, K. Müllen, J. P. Rabe, Adv. Mater. 2000, 12, 579.

[86] V. Samorí P.Francke, K. Müllen, J. P. Rabe, Chem. Eur. J. 1999, 5, 2312-2317.

[87] K. Kuroda, T. M. Swager, Macromolecules 2004, 37, 716-724.

[88] Even though we consistently observed fluorescence intensity drop caused by the directly attached carboxylic acid group through various conjugated polyelectrolytes, oligomers with directly attached carboxylic acids having a large quantum yield were also reported: C. A. Stanier, M. J. O'Connell, W. Clegg, H. L. Anderson, Chem. Commun. 2001, 493.

[89] H. Häger, W. Heitz, Macromol. Chem. Phys. 1998, 199, 1821-1826.

[90] R. J. Perry, B. D. Wilson, S. R. Turner, R. W. Blevins, Macromolecules 1995, 28, 3509-3515.

[91] J. Zhang, Y. Cui, M. Wang, Liu, J. Chem. Commun. 2002, 2526-2527.

[92] Q. Zhou, T. M. Swager, J. Am. Chem. Soc. 1995, 117, 12593-12602.

[93] U. Lauter, W. H. Meyer, V. Enkelmann, G. Wegner, Macromol. Chem. Phys. 1998, 199, 2129-2140. 